\title{
CHASING THE EMERGING TREND OF ICT: THE CHALLENGES FACED BY ESL TEACHERS AND THEIR ATTITUDE IN INTEGRATING ICT IN RURAL SCHOOLS OF TATAU DISTRICT
}

\author{
Vanessa Jill Anak James Berok ${ }^{1}$ \\ Faculty of Education, \\ Universiti Kebangsaan Malaysia (UKM), Malaysia \\ (Email: vanessajilljames@yahoo.com) \\ Melor Md Yunus ${ }^{2}$ \\ Faculty of Teaching \& Learning Innovation, \\ Universiti Kebangsaan Malaysia (UKM), Malaysia \\ (Email: melor@ukm.edu.my)
}

Accepted date: 16-03-2019

Published date: 09-07-2019

To cite this document: Berok, V. J. J., \& Yunus, M. M. (2019). Chasing the Emerging Trend of ICT: The Challenges Faced by ESL Teachers and Their Attitude in Integrating ICT in Rural Schools of Tatau District. Journal of Information System and Technology Management, 4(13), 84-96.

DOI: $10.35631 / J I S T M .413008$

\begin{abstract}
The utilization and integration of Information and Communication Technologies (ICT) have enabled the establishment of virtual learning environments that are capable of developing English language skills among Malaysian primary pupils. The Ministry of Education had invested a substantial amount of money on ICT as a part of education initiatives to ensure there will be no gap on the quality of education between urban and rural schools. However, the usage of ICT in rural schools could not meet the expectations. This case study takes a closer look at the challenges faced by the ESL teachers and their attitude in integrating ICT in teaching and learning process based on Technology Acceptance Model (TAM). A total of 11 English teachers from 6 rural schools in Tatau, Sarawak were selected based on purposive sampling. Data was collected via questionnaire and calculated using percentage. It was then analysed and semi-structured interview was later conducted. The findings revealed that although teachers' attitude toward ICT integration in rural school was positive and it had enhanced their performance in teaching and learning, the actual use was the practicality of integrating ICT. The findings also revealed poor Internet connection, limited facilities and infrastructure were the challenges that had influenced their behaviour in using ICT which put a limitation of its usage.
\end{abstract}

Keywords: ICT Integration, Rural Schools, TAM, Case Study 


\section{Introduction}

Information and Communication Technology (ICT) is integrated into the teaching and learning process in various educational institutions globally (Singh \& Chan, 2014). The use of ICT has transformed the way educators delivered, organised and structured their lessons (Hong, Chai, Tan, Hasbee, \& Ting, 2014). ICT is also seen as a core element in today's classroom because it has been universally accepted that the $21^{\text {st }}$ century education is online, interactive, open, distributed and widely accessible (J.A.Kumar, Osman, \& Pranchis, 2018). It is not only considered as a tool for existing teaching methods, but currently it is seen as an important instrument as well as an innovation to support new ways of teaching and learning process.

In October 2011, The Ministry of Education (MOE) had launched a comprehensive review of education system in Malaysia. A new education blueprint was developed to raise the national education standards to equip students all around Malaysia with $21^{\text {st }}$ century skills. Prior to that, the MOE developed three major plans for using ICT in Education. The first plan is to put emphasis on ICT as an enabler to decease the existing digital gap between the schools. The second plan emphasizes the use of ICT as an educational tool for obtaining and communication information. The third plan focusses on ICT in enhancing productivity, effectiveness and efficiency of the management system (Yunus, Nordin, Salehi, Embi, \& Salehi, 2013). Currently, Malaysia Education Blueprint (2013-2025) is introduced by the government as a stepping stone for a sustainable transformation of our education system.

\section{Literature Review}

An effective use of ICT in teaching and learning is very much depending on the preparation of the teachers. However, the knowledge level of the Malaysia teachers on ICT is moderate as they were only good at using certain applications which are commonly used in teaching profession (Singh \& Chan, 2014). A research on ICT Tools in Teaching and Learning Literature Component in Malaysian Secondary Schools was conducted and slightly more than half of the teachers used ICT tools in teaching Literature, but they only utilised it for general usage such as typing and preparing PowerPoint slides (Yunus \& Suliman, 2014). Mantoro \& Ayu (2015) revealed $80 \%$ of teachers have lack of knowledge in software or website that support teaching and learning. The findings of their research shows that most of the teachers with more than 10 years of teaching experience have never attended a formal training in using ICT.

A survey was conducted on the attitude among ESL teachers towards the use of ICT and the result shows that a majority of the respondents agree that the use of computer stresses them out because they do not know how to fix it if something goes wrong (Kandasamy \& Shah, 2013). Kandasamy \& Shah reported more than half of the respondents agreed that computer is not conducive to good teaching because it creates technical problems. Tan (2016) claimed that teachers who are computer literate in average urban schools that has a computer lab or resource room equipped with sufficient computers also faced technical problems with connectivity, hardware breaking down, software incompatibility, obsolete equipment and any other problems. Inaccessible and unavailable of internet access contribute to a major challenge that put a stop to teachers' intentions on using ICT tools (Shah \& Empungan, 2015). They added, insufficient or outdated and incompatible ICT software and hardware were also a part of the challenges faced by them. Thus, a mere exposure to the basic technological knowledge and skills in training programmes, does not assure that technological innovations would be established in ESL instruction (Aziz, 2017). 
Aziz (2017) echoed on teachers' readiness and willingness to embrace and adopt change in technological innovations may not have a lasting presence in ESL instruction. She elaborates without the supportive conditions or measures undertaken to facilitate the ongoing process by their schools or entrusted administrative bodies to implement the task, the integration of ICT in ESL classroom incline to fail. When teachers are not providing insights on the implementation of ICT in learning English, it limits them to further enhance their development to achieve their full potential. Hence, this study is to investigate teachers' attitude towards integrating ICT in rural ESL classroom and identify the challenges faced by ESL teachers in integrating ICT in rural ESL classroom

\section{Teachers' Challenges in Integrating ICT for ESL Classroom}

Yamat \& Singh (2016) classify workload, lack of time, teaching experience and age, and lack of ICT skills as barriers to incorporate ICT tools in ESL classroom. In their research, teachers are over-loaded with administrative tasks and put their focus on examinations and syllabi. They revealed that ICT is challenging to integrate with classes which consist of huge number of students while at the same time burdened with marking examination papers, exercise books and workbooks.

According to Samuel \& Bakar (2006), senior teachers have not attended any computer courses at all. They explained that these teachers are avoiding the courses and directing other younger teachers to go as they are fearful of being ridiculed by fellow teachers of being incompetent. Hence, they incorporated ICT tools in their instructional practices far lesser than younger teachers (Rahimi \& Yadollahi, 2011). Little structural support from school administration and rigid curriculum were also some of the prominent factors which cause the hindrance of using ICT among teachers (Shah \& Empungan, 2015). While they are lacking of administrative support, teachers who are not confident enough to operate ICT tools have so little time to manage and get familiarize with the ICT tools. For example, FrogVLE software that is currently and widely used in Malaysian schools might be impracticable if the teachers fail to operate basic computer skill. Thus, having a fully equipped hardware, software and programs will not guarantee learners full benefits and opportunities of learning English (Bakar, 2017).

Inadequate basic infrastructures in school as well as lack of maintenance and technical support and power supply may make blending education and technology at lower level of farce (Adeosun, 2010). However matters such as maintenance and technical support are not within the control of the school principal, it requires bureaucratic procedures to solve the funding and infrastructures (Tan, 2016). There are plenty of rural schools in Malaysia where 1BestariNet is provided as one of Ministry's initiatives, but is not fully utilized because of the lack of technical support and poor infrastructures. Classroom technical problem has become a common issue in the rural schools and because of the bureaucratic procedures in tackling this issue, teachers have long forgotten and put an end to the blending of technology in their lesson.

\section{Teachers' Attitude towards the Integration of ICT in ESL Classroom}

Albirini (2006) classifies attitudes into three elements: affect, cognition and behaviour. Affective element is associated to the individuals' emotional state. Cognitive element emphasizes on individuals' knowledge and behavioural element is the overt behaviour. For example, Gilakjani \& Leong (2012) claim some teachers show a little interest in using ICT, while others are still obviously resistant to its use. There are also others who have feelings of uncertainty, hostility and fear which naturally lead to many of them reluctant or resist technological innovation. Their computer literacy are at disadvantage, so they continue to adhere to their traditional practices where they are still in their comfort zone. 
According to Gandhi \& Lynch (2016), teachers have positive perceptions towards ICT only if they have strong knowledge in it and are well supported by school. The positive attitude will also motivate the students to learn and not fear of using ICT. Simin \& Sani (2015) also state that ICT tools and equipment will prepare an active learning environment that is more interesting and effective for both teachers and students. Teachers need to perceive that education technology will add value to the teaching experience for the integration to be successful, but underlined the skills to use technology are not enough for the successful integration of education technology into schools (Hart \& Laher, 2015)

Safitry, et al. (2015) concluded, even though some teachers felt comfortable using ICT, some of them also agree that using ICT in the classroom activity made them felt depressed. They believed the problem appeared due to the lack of knowledge on how to apply ICT and the knowledge on software or website to support teaching, also the lack of technical support from the schools. Similar findings can be found in a research carried out by Raman \& Yamat (2014), they reported that the barriers such as lack of time, workload, teaching experiences and age, lack of ICT skills and the negative attitudes of teachers towards ICT are hindering the teachers to integrate ICT in English classroom.

According to Gilakjani \& Leong (2012), positive attitudes toward technology integration develop learning to use technologies in teaching and learning while negative attitudes constrain it. Nevertheless, it does not necessarily mean that teachers with positive attitude should be included in technology training activities or courses. It means that negative attitudes among them need to be acknowledged and addressed, and that positive attitudes should be encouraged and developed.

\section{Technology Acceptance Model (TAM)}

ICT offers great potential for substantial improvements and performances in the field of education, but performance gain depends on users' willingness to accept the available system. Many theories have been proposed to explain the relationship between attitude and the actual system use. The most suitable framework to measure technology acceptance among users is Technology Acceptance Model.

Davis (1993) clarifies TAM as to address why users accept or reject information technology and how user's acceptance is influenced by the system characteristics. In other words, this model suggests that when users are presented with innovation, a few factors influence their decision about how they will use it (Wario, 2014). These factors include Perceived Usefulness (PU) and Perceived Ease of Use (PEU). PU is the degree to which the users believe that using a particular system can enhance his or her job performance while PEU is the degree to which the users believe that using a particular system is free of effort (Davis, 1989).

According to TAM, Behavioural Intention to Use (BI) describes the actual use of a given Actual System Use and determined the technology acceptance (Alharbi \& Drew, 2014). They added the Attitude toward Using (A) and PU influence by BI. BI is also indirectly affected by PEU. A is directly affected by both PU and also PEU while PU is directly influenced by PEU. Thus, TAM theory suggest PU and PEU are affected by the external variables which mediate the effect of external variables on users' attitude and behavioural intention, and therefore the actual system use. 


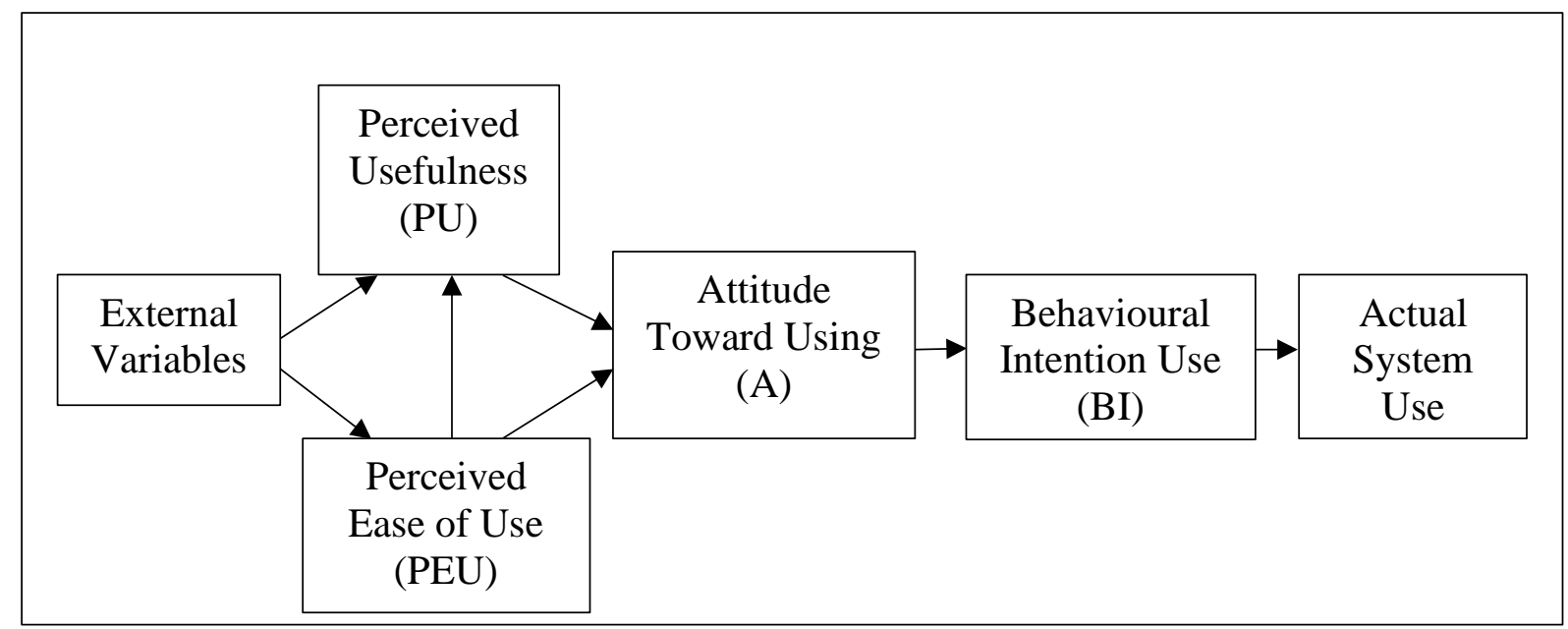

Figure 1: Technology Acceptance Model

\section{Methodology}

A total of 11 teachers from 6 different rural schools in the district of Tatau were selected based on purposive sampling. These rural schools are categorized as Pedalaman 3 which signify as the most remote schools in the district. The priority in selecting the respondents are given to English option teachers, however schools that had no English option teachers were selected based on the subject taught. They were given questionnaire to be completed and semistructured interview was conducted afterwards.

\section{Instruments}

Questionnaire was used to collect information regarding this respondents' attitude and challenges integrating ICT in rural ESL classroom. The items were adapted and adopted from Hong, Chai, Tan, Hasbee \& Ting (2014) based on their research paper on ESL Teachers' Computer Self-Efficacy, Attitudes Toward Computer and Classroom Computer Use and Kandasamy \& Shah (2013) based on their research paper on Knowledge, Attitude and Use of ICT Among ESL Teachers. The questionnaire for the respondents were divided into 5 sections: Teachers' demographic background, Knowledge level possessed by ESL teachers in using ICT, Attitude towards ICT, Classroom computer use and The challenges faced by teachers in using ICT.

The purpose of this semi structured interview was to validate all the research questions. There were three questions adapted from Singh \& Chan (2014) in their journal of Teacher Readiness on ICT Integration in Teaching-Learning: A Malaysian Case Study for this interview. These interview questions were conducted to further investigate the attitude real challenges faced by the respondents while integrating ICT in ESL classroom.

\section{Data Analysis and Results}

\section{Demographic Background}

The respondents represent $45.5 \%$ male and $54.5 \%$ female English teachers. As for teaching experience, $81.8 \%$ have been teaching for less than 5 years and $18.2 \%$ have been teaching more than 5 years. This reflect rural schools are lack of experienced English teachers in Tatau district. On the plus side, $100 \%$ of respondents have been using computer for more than 5 years. The majority of the respondents received formal training which comprises of $81.8 \%$ and only $18.2 \%$ did not receive any formal training for computers. 
Table 1: Gender

\begin{tabular}{ccc}
\hline Gender & No. of Respondent & Percentage (\%) \\
\hline Male & 5 & 45.5 \\
Female & 6 & 54.5 \\
\hline
\end{tabular}

Table 2: Teaching Experience

\begin{tabular}{ccc}
\hline Teaching Experience & No. of Respondent & Percentage (\%) \\
\hline Less than 5 years & 9 & 81.8 \\
More than 5 years & 2 & 18.2 \\
\hline
\end{tabular}

Table 3: Using Computer

\begin{tabular}{ccc}
\hline Using Computers & No. of Respondent & Percentage (\%) \\
\hline Less than 5 years & 0 & 0 \\
More than 5 years & 11 & 100 \\
\hline
\end{tabular}

Table 4: Formal Training

\begin{tabular}{ccc}
\hline Formal Training & No. of Respondent & Percentage (\%) \\
\hline No & 2 & 18.2 \\
Yes & 9 & 81.8
\end{tabular}

Differences in Knowledge Level Possessed By ESL Teachers in Using ICT

Each of the statement in this section were rated from excellent, good, fair and no capability. In Table 5 below, a majority of the respondents which comprises $54.5 \%$ possessed excellent knowledge in Word Processing as well as PowerPoint and $36.4 \%$ of respondents acquired good knowledge in both applications. $64 \%$ of respondents are excellent in E-mailing and Internet browsing and $27.3 \%$ are good. On a positive notation, only $9.1 \%$ among all the respondents are fair in Word Processing, PowerPoint, E-mailing and Internet browsing. The percentages of excellent in all these applications and software are higher because it is used by respondents in their teaching and learning process.

However, only $9.1 \%$ of respondent rate themselves as excellent in using Spread Sheet, 54.5\% consider themselves to be good and the remaining $36.4 \%$ measured themselves to be fair. The result revealed a minority of the respondents rated themselves as excellent on their knowledge in Spread Sheet because it is the least application used in teaching and learning of ESL classroom. None of these respondents have no capabilities in operating application or software which indicate the $81.8 \%$ of respondents in Table 4 who had received formal training were effective.

Table 5: Knowledge Level Possessed by ESL Teachers in Using ICT

\begin{tabular}{ccccc}
\hline Statement & Excellent (\%) & Good (\%) & Fair (\%) & No Capability (\%) \\
\hline $\begin{array}{c}\text { Word Processing } \\
\text { (Microsoft Word) }\end{array}$ & 54.5 & 36.4 & 9.1 & 0 \\
Spread Sheet & 9.1 & 54.5 & 36.4 & 0 \\
(Excel) & & & & \\
PowerPoint & 54.5 & 36.4 & 9.1 & 0 \\
E-mailing & 63.6 & 27.3 & 9.1 & 0 \\
Internet Browsing & 63.6 & 27.3 & 9.1 & 0 \\
\hline
\end{tabular}




\section{Attitude towards ICT among ESL Teachers}

In this section, each statement is rated as disagree, neutral and agree. Most of the respondents showed positive attitude towards ICT. All of the respondents agreed feeling comfortable using ICT as a tool in teaching and learning. 90.9\% of them disagree using computer in the classroom stresses them out. Less than half of the respondents will know how to fix if something goes wrong, but $27.3 \%$ felt neutral which denote they might or might not be able to fix it. A handful of them $(63.6 \%)$ agree and $36.4 \%$ feeling neutral to the statement that the use of ICT in teaching and learning excites them. $18.2 \%$ of the respondents disagree and another $18.2 \%$ are neutral that the computer is a valuable tool for teachers. $63.6 \%$ agree upon that it is a valuable tool. The statement computer will change the way pupils learn during lesson is agreed by $63.6 \%$ of the respondents respectively and the remaining $36.4 \%$ are neutral.

There are $72.7 \%$ of respondents disagree the computer is not conducive to pupils' learning because it is not easy to use. On the contrary, a surprising number of percentage, $9.1 \%$ of respondent agree to the statement. The percentage of the statement the computer helps pupils understand concepts in more effective ways between neutral and agree are $45.5 \%$ and $54.5 \%$. A majority of $72.7 \%$ of respondents agree the computer helps teachers to teach in more effective ways but $9.1 \%$ disagree because it creates technical problems and that $9.1 \%$ is of similar respondent.

Table 6: Attitude towards ICT

\begin{tabular}{llccc}
\hline No $\quad$ Items & Disagree (\%) & Neutral (\%) & Agree (\%) \\
\hline 1. $\quad \begin{array}{l}\text { I feel comfortable using ICT as a tool in } \\
\text { teaching and learning. }\end{array}$ & 0 & 0 & 100.0 \\
2. Using computer in the classroom stresses me & 90.9 & 9.1 & 0 \\
$\quad \begin{array}{l}\text { out. } \\
\text { If something goes wrong I will not know how } \\
\text { to fix it. }\end{array}$ & 45.5 & 27.3 & 27.3 \\
$\quad \begin{array}{l}\text { The use of ICT in teaching and learning } \\
\text { excites me. }\end{array}$ & 0 & 36.4 & 63.6 \\
$\begin{array}{l}\text { The computer is a valuable tool for teachers. } \\
\text { The computer will change the way pupils learn } \\
\text { during my lesson. }\end{array}$ & 18.2 & 18.2 & 63.6 \\
$\quad \begin{array}{l}\text { The ICT is not conducive to pupils' learning } \\
\text { because it is not easy to use. }\end{array}$ & 72.7 & 18.2 & 9.1 \\
$\quad \begin{array}{l}\text { The computer helps pupils understand } \\
\text { concepts in more effective ways. }\end{array}$ & 0 & 45.5 & 54.5 \\
$\quad \begin{array}{l}\text { The computer helps teachers to teach in more } \\
\text { effective ways. }\end{array}$ & 9.1 & 18.2 & 72.7 \\
$\begin{array}{l}\text { The computer is not conducive to good } \\
\text { teaching because it creates technical problems. }\end{array}$ & 63.6 & 27.3 & 9.1 \\
\hline
\end{tabular}

\section{Classroom Computer Use In ESL Classroom}

Table 7 shows the result of classroom computer use in rural ESL classroom. The statements are rated as often, seldom and never. Nearly half of the respondents, $54.5 \%$ seldom use computer to teach English. Yet, $63.6 \%$ of respondents often use computer and projector to play films. $72.7 \%$ of respondents admitted they seldom used computer software to demonstrate lesson contents. On the contrary, a great amount of respondents $(81.1 \%)$ download English 
Language teaching and learning resources to enhance pupils' learning. Only $9.1 \%$ of respondents seldom and never download the resources.

As for using instructional software provided by the Education Department to teach English, $45.5 \%$ seldom use it and $27.3 \%$ respondents represent often as well as never. Although they showed positive attitudes towards the use of ICT in ESL classroom, less than half of them (36.4\%) often use computer to integrate English learning skills. $63.6 \%$ of them seldom practice it also seldom using computer to assist pupils in their individual learning. Only $18.2 \%$ of respondents often use the computer to assist their pupils and also $18.2 \%$ never do so.

Table 7: Classroom Computer Use

\begin{tabular}{|c|c|c|c|c|}
\hline No & Items & Often $(\%)$ & Seldom (\%) & Never $(\%)$ \\
\hline 1. & I use computer to teach English & 45.5 & 54.5 & 0 \\
\hline 2. & $\begin{array}{l}\text { I use computer and projector to play } \\
\text { films }\end{array}$ & 63.6 & 36.4 & 0 \\
\hline 3. & $\begin{array}{l}\text { I have used computer software to } \\
\text { demonstrate lesson contents }\end{array}$ & 27.3 & 72.7 & 0 \\
\hline 4. & $\begin{array}{l}\text { I download English Language } \\
\text { teaching and learning resources to } \\
\text { enhance pupils' learning }\end{array}$ & 81.8 & 9.1 & 9.1 \\
\hline 5. & $\begin{array}{l}\text { I use instructional software provided } \\
\text { by the Education Department to teach } \\
\text { English }\end{array}$ & 27.3 & 45.5 & 27.3 \\
\hline 6. & $\begin{array}{l}\text { I use computer - based technology to } \\
\text { integrate English learning skills }\end{array}$ & 36.4 & 63.6 & 0 \\
\hline 7. & $\begin{array}{l}\text { I use the computer to assist pupils in } \\
\text { their individual learning }\end{array}$ & 18.2 & 63.6 & 18.2 \\
\hline
\end{tabular}

The Classroom Challenges Faced By Teachers Using ICT

There are 5 items rated often, seldom and never for Table 8 . For the classroom challenges faced by teachers using ICT, $45.5 \%$ of respondents declared that they had never experienced lack of technical support. $36.4 \%$ of them claim they had often experience lack of technical support and $18.2 \%$ seldom. $45.5 \%$ of respondents seldom experience lack of time in school when using ICT in the classroom, $36.4 \%$ rate themselves as often and $18.2 \%$ as never. $63.6 \%$ of respondents consider themselves have adequate knowledge on how to make use of ICT. Only $9.1 \%$ often experience limited understanding on how to make full use of ICT and $36.4 \%$ seldom, which shows the respondents are literate in ICT.

Almost all of them (72.7\%) had never had limited understanding on how to integrate ICT into teaching and a minority of $27.3 \%$ of respondents seldom and $9.1 \%$ of them never experience it. $27.3 \%$ of respondents often and never lack of software or website that support teaching and learning, but $45.5 \%$ of them seldom.

Table 8: Challenges Faced by Teachers in using ICT

\begin{tabular}{llccc}
\hline No & Items & Often (\%) & Seldom (\%) & Never (\%) \\
\hline 1. & Lack of technical support & 36.4 & 18.2 & 45.5 \\
2. & Lack of time in school & 36.4 & 45.5 & 18.2 \\
3. & Limited knowledge on how to make full use & 9.1 & 36.4 & 63.6
\end{tabular}


4. Limited understanding on how to integrate

5. Lack of software or website that support teaching and learning

\section{Discussion}

\section{Teachers' Attitude towards the Integration of ICT in ESL Classroom}

From the findings, teachers showed positive attitude towards the integration of ICT in ESL classroom. During the course of this research, a semi-structured interview was carried out. Some of the respondents were proven exhibiting positive attitude. Two-thirds of the respondents noted that integrating ICT had helped them to teach in a more effective way. Respondent 1, a teacher who had been teaching for less than 5 years explained,

"ICT helps the teachers to assist learning in a more meaningful way, although there were some hiccups but it doesn't really stop me from using it. As for my school, it excites the pupils when ICT is involved in the classroom. I just have to put more effort in my teaching so that my learning outcomes are tangible."

Respondent 2 had put her thoughts in the interview session where ICT can bring great experience for the pupils.

"Rural pupils should be given more exposure to the ICT since the school is the only place where they can learn using ICT. Besides, the ICT will help teachers to bring the outside world into the classroom. It will be such a great experience for the pupils."

Respondent 10 also had similar opinion on ICT,

"It changes ways of teaching and it promotes self-learning among the pupils."

Respondent 7, who had received formal training in using computer commented,

"I believe that using ICT will help the pupils especially in the rural area for them to know the current issues easily. ICT is one of the solutions to engage pupils with their learning. Instead of using newspaper as my teaching material, I showed them videos of current issues. I think learning is more exciting and relatable that way."

These respondents believed that the integration of ICT in ESL classroom contribute to the effectiveness of teaching and learning. This can be proven and agreed by Simin \& Sani (2015), where ICT tools and equipment are able to prepare an active learning environment which is far more interesting and effective for both teachers and students. As the results of this study reported that a majority of respondents agreed that computer is a useful tool and it helps pupils to understand concepts in an effective way, therefore, teachers PU is verified whereby the use of ICT can improve their teaching performance. It was confirmed by Davis (1989) where PU is define as a particular system that can enhance his or her job performance. 9 out of 11 respondents were competent in computer as they had received formal training which they can be classified as experienced in ICT. This is because teachers' attitudes toward computer technologies are related to their computer competence (Gilakjani \& Leong, 2012). Hence, teachers PU does depend on their knowledge in the use of computer. 


\section{Challenges Faced By ESL Teachers in Integrating ICT for ESL Classroom}

Based on the result from the questionnaire, more than half of the respondents know how to make use and integrate ICT in Teaching and learning, but it was not fully utilised due to certain hindrances. Interviews with the respondents revealed that one of the most common challenges in integrating ICT for ESL classroom in rural school is poor Internet connection. There are a few claims made by the respondents:

Respondent 1: "Sometimes, there are materials that I want to download to make the lesson fun. Due to poor Internet connection, I am unable to do so. The lesson became less fun for the pupils."

Respondent 5: "I never use the Internet for my lesson. Usually, I would download my materials online over the weekend for my next lesson. You see, most of the teachers in my school are competent in ICT, but we gave up on using Internet in our class because it takes so much effort."

Respondent 9: "The Internet access is too slow even via VSAT or telco. So I stop using the Internet because it's a waste of time."

There were also a few challenges underlined by the respondents. Respondent 9 shared his concern regarding the 1 BestariNet Chromebook provided by MOE,

"The laptop provided for the pupils are outdated and mostly cannot be used anymore. These laptops are just sitting there as display stored in a container because my school has no space to create even for an ICT room or laboratory. We don't have enough building to accommodate it."

Some of these respondents are enthusiastic to integrate ICT in ESL classroom, but during the implementation stage their willingness to do so decreases. According to Respondent 2,

"Teachers have to take turns in using the LCD projector and laptops because it is limited. Our computer laboratory, library and classrooms have limited power supply. It demotivates me from utilising these facilities."

There were 3 out of 11 respondents admitted they find integrating ICT consumed too much time. The process of installing equipment or hardware is time consuming and they had to catch up with the syllabi.

From the result, most of the knowledge level possessed by the respondents on ICT fall under excellent and good. As anticipated, when teachers perceived ICT as easy to use (PEU), they developed positive attitude towards utilising it which improves their performance (PU). Hence, PEU and PU influence their attitude in using (A) ICT which afterward affected their behaviour (BI). Similarly as stated by Alharbi \& Drew (2014), the perceived usefulness increased the degree of positivity toward usage which subsequently affected the behavioural intention to use. In this case, the challenges faced by the respondents influenced BI too. They perceived ICT as easy to use also believed it can enhance their performance, nonetheless the challenges they faced had put some hindrances to fully utilise ICT in ESL classroom. 


\section{Conclusion and Recommendations}

Based on the results and findings of this study, teachers need to be provided with sufficient resources with adequate facilities to make the integration of ICT convenient. Teachers should be given continuous technical support by which not only based on the ICT tools provided, but also improving on school infrastructure. Most of the schools in rural area were provided with Chromebooks but they were out of order or tend to break down faster due to 'many hands' using it. The interview findings revealed even if they have functional Chromebooks, they were not fully utilised because the schools had no proper computer laboratory.

The school Internet is another teething problem where it should be urgently looked into. 1BestariNet was provided but it had come into a failure. The school Wi-Fi had never been smooth and it ought to be improved to enable teachers to integrate ICT in their teaching and learning process. Searching for resources via online, using online application and software can help teachers to provide effective lesson. Although the MOE had continuously sending more and more teachers to go courses or training to upskill the usage of ICT, the lack of facilities had defeat the purpose of these trainings.

The administrations should be aware of the existing of ICT facilities are at paramount importance. The administrations should provide teachers with administrative support where conditions of integrating ICT should be met such as adequate classroom facilities, sufficient power supplies and projectors, good Internet connection, conducive computer laboratory and functional devices to ensure the successfulness of ICT integration. Hence, continuous technical support should be practise.

Software and hardware used during ESL lessons were also identified which lead to the actual used of the system based on TAM. All of the respondents were found to possess positive attitudes towards ICT integration though the actual use of ICT in teaching and learning process was not extensively used. The findings reported all the respondents were competent in ICT because most of the respondents were less than 5 years of teaching experienced and were well trained in teacher institutions. This was the actual reason the respondents hold positive attitudes as discussed previously. Although the actual use system of ICT in ESL classroom indicated to enhance respondents' performance in teaching, the challenges they faced had put limitations to take full advantage of utilizing it. The challenges created a few hindrances which influenced respondents' behaviour. As semi-structured interview was conducted, level of motivation came across during the conversation. This leads to consider possible beliefs that TAM should add motivation, not just PEU and PU that influence respondents A and BI to identify their actual system use. Motivation did affect BI because these respondents were facing challenges to conduct lessons without Internet connection, limited power supply as well as facilities and resources. From this perspective, an individual's affect toward using a given system is determined by their motivation of using the system (Davis, 1993). This can be consider as another variable in TAM.

Another interesting finding in comparison to other existing research, the respondents had not fully stop integrating ICT in their classroom but had found practical alternatives to adapt to the classroom environment. The respondents indicated that they were comfortable in using computer, yet when it comes to employing the integration of ICT, they were facing technical difficulties which consumed a colossal amount of time. They had positive attitude towards the use of ICT but for some respondents who had poor facilities in their school, the implementation do not demonstrate the attitude. They integrated ICT hoping it can provide variety of opportunities for the pupils and enhanced their teaching strategy, but the lack of technical 
support forced them to only focus on Microsoft Office and the available hardware in school to assist the implementation.

However, this situation only applies in rural schools of Pedalaman 3 in Tatau district as this research only represent ESL teachers that had been teaching for less than 10 years. These young respondents incorporate ICT tools far more often compared to older teachers as proven by Rahimi \& Yadollahi (2011) whereby older teachers are lack of confidence in integrating ICT and has higher level of computer anxiety. This research finding had led to positive attitude toward using ICT because a majority of ESL teachers in rural schools of Pedalaman 3 are young. 9 out of 11 respondents were formally trained in using computer and had attended courses to upskill ICT in $21^{\text {st }}$ century learning, yet they are only applying a fraction of the knowledge and the skills in fulfilling the current demands of $21^{\text {st }}$ century learning. The level of difficulties in using ICT is not a huge concern to the respondents but the practicality of implementing it influenced their A and BI.

Therefore, respondents perceived the use of ICT was to enhance their performance in teaching and the ease of use was not really a concern, but practicality of implementing ICT was. It created positive attitude because they were competent and were able to adapt to the challenges they faced. The challenges had influenced their behaviour in integrating ICT that had led to actual system use.

\section{References}

Adeosun, O. (2010). Quality Basic Education Development in Nigeria: Imperative for Use of ICT. Journal of International Cooperation in Education, Vol. 13, 193-211.

Albirini, A. (2006). Teachers' Attitudes Toward Information and Communication Technologies: The Case of Syrian EFL Teachers. Computers \& Education, 373-398.

Alharbi, S., \& Drew, S. (2014). Using the Technology Acceptance Model in Understanding Academics' Bahavioural Intention to Use Learning... International Journal of Advanced Computer Science and Applications (IJACSA), 143-155.

Aziz, N. A. (2017). Taking Concerns Into Account: Understanding The Technology Adoption Process From The ESL Teachers' Point Of View. The English Teacher Vol. XXXVII, 76-89.

Bakar, N. A. (2017). English Language Activities In Computer-Based Learning Environment: A Case Study In ESL Malaysian Classroom. GEMA Online Journal of Language Studies, Vol. 7, 33-49.

Davis, F. D. (1989). Perceived Usefulness, Perceived Ease of Use, and User Acceptance of Information Technology. MIS Quarterly, 319-340.

Davis, F. D. (1993). User Acceptance of Information Technology: System Characteristics, User Perceptions and Behavioral Impacts. Int. J. Man - Machine Studies, 475-487.

Gandhi, H. K., \& Lynch, R. (2016). A Comparative Study of Teachers' Knowledge of Common ICT Software, Their Perceptions Towards Using ICT and Their Perceived SelfConfidence in Integrating ICT In Their Classes According to Gender in Two International Schools In Thailand. Scholar: Human Sciences, Vol 8, No 2, 78-93.

Gilakjani, A. P., \& Leong, L.-M. (2012). EFL Teachers' Attitudes Toward Using Computer Technology in English Language Teaching. Theory and Practice in Language Studies, Vol. 2, 630-636.

Hart, S. A., \& Laher, S. (2015). Perceived Usefulness and Culture As Predictors of Teachers Attitudes Toward Educational Technology in South Africa. South African Journal of Education, Vol 35, No 4, 1-13. 
Hong, K. S., Chai, M. L., Tan, K. W., Hasbee, U., \& Ting, L. (2014). ESL Teachers' Computer Self-Efficacy, Attitudes Toward Computer and Classroom Computer Use. Social Sciences \& Humanities, 369-385.

Kumar, J.A., Osman, S., \& Pranchis, R. (2018). A Preliminary Study on Pre-Service Tesol Teachers' Attitudes Towards The Use of ICT for Teaching in Malaysia. Journal of Fundamental and Applied Sciences, 1269-1278.

Kandasamy, M., \& Shah, P. B. (2013). Knowledge, Attitude and Use of ICT Among ESL Teachers. GSE Journal of Education, 185-199.

Rahimi, M., \& Yadollahi, S. (2011). Computer Anxiety and ICT Integration in English Classes Among Iranian EFL Teachers. Procedia Computer Science, 203-209.

Raman, K., \& Yamat, H. (2014). Barriers Teachers Face in Integrating ICT During English Lessons: A Case Study. The Malaysian Online Journal of Education Technology, Vol. 2, Issue 3, 11-19.

Safitry, T. S., Mantaro, T., Ayu, M. A., Mayumi, I., Dewanti, R., \& Azmeela, S. (2015). Teachers' Perspective and Practices in Applying Teachnology to Enhance Learning in the Classroom. International Journal of Emerging Technologies in Learning (iJET), $10-14$.

Samuel, R. J., \& Bakar, Z. A. (2006). The Utilization and Integration of ICT Tools in Promoting English Language Teaching and Learning: Reflections From English Option Teachers in Kuala Langat District, Malaysia. International Journal of Education and Development Using Information and Communication Technology (IJEDICT), 4-44.

Shah, P. M., \& Empungan, J. L. (2015). ESL Teachers' Attitude towards Using ICT in Literature Lessons. International Journal of English Language Education, 201-218.

Simin, G., \& Sani, I. M. (2015). Effectiveness of ICT Integration in Malaysian Schools: A Quantitative Analysis. International Research Journal for Quality Education, Vol. 2, $1-12$.

Singh, T. K., \& Chan, S. (2014). Teacher Readiness on ICT Integration in Teaching-Learning: A Malaysian Case Study. International Journal of Asian Social Science, 874-885.

Tan, K.-E. (2016). Internet Integration as Sociocultural Practices by Urban English Teachers in Malaysia. Arab World English Journal, 48-62.

Wario, R. D. (2014). Attitudes Towards Computer Usage As Predictors of The Classroom Integration of Information and Communication Technology At A Rural South African University. (s.1.): (s.n.).

Yamat, H., \& Singh, K. K. (2016). What Primary School Teachers Say About Their Beliefs on Teaching and Learning. Jurnal Pendidikan Malaysia, 125-130.

Yunus, M. M., \& Suliman, A. (2014). Information \& Communication Technology (ICT) Tools in Teaching and Learning Literature Component in Malaysia Secondary Schools. Asian Social Science, 136-152.

Yunus, M. M., Nordin, N., Salehi, H., Embi, M. A., \& Salehi, Z. (2013). The Use of Information and Communication Technology (ICT) in Teaching ESL Writing Skills. Canadian Center of Science and Education, 1-8. 